\title{
The Legacy of Lunacharsky and Artistic Freedom in the USSR
}

Since the Twentieth Party Congress, a controversy has developed in the Soviet Union concerning the activities and views of Anatolii Vasilievich Lunacharsky (1875-1933). Lunacharsky was the USSR's first commissar of education and an important and controversial figure in the arts during the 1920s. Of particular interest in the current debate is the underlying issue of artistic freedom in the Soviet Union today. In praising or attacking Lunacharsky, writers can set forth in an oblique manner their views on topics that cannot always be openly discussed. In this debate those who advocate change in the arts policy and those who support the current policies can confront each other, in an acceptable way, on such issues as censorship, the party's role in the world of art, artistic experimentation, and a variety of other issues of vital concern to artists and writers in the Soviet Union.

In recent years the attention focused on Lunacharsky has increased in both intensity and volume. Between 1933 (the year of his death) and 1956 little of value or significance was written about him. Between 1956 and 1967, however, more than sixty articles concerning Lunacharsky, containing a wide variety of views and interpretations, appeared in Soviet publications. It is significant that the Lunacharsky debate commenced in 1956, for it was part of a larger trend in Soviet literary and critical activity that began in that year. According to Vasilii Ivanov, a prominent scholar of Soviet cultural development, Soviet scholars embarked on a "re-evaluation of literary trends in the 1920 s pointing toward the positive contributions of a number of groups active in this period." Ivanov described this trend as part of "the ideological battles spawned by the Twentieth Party Congress ... [ [during which] an attempt was made to lead a furious attack on the fundamentals of Marxist-Leninist aesthetics in the hopes of loosening them up."

A. A. Lebedev, an academician who has written several studies on Lunacharsky, pointed out that the debate over Lunacharsky was part of this trend, and applauded the "return of Lunacharsky to Soviet readers" as a result of the reinterpretations of the 1920 s. $^{2}$ Lebedev claimed that during the

1. Vasilii Ivanov, "O literaturnykh gruppirovkakh i techeniiakh 20-kh godov," Znamia, 1958, no. 6, p. 190.

2. A. A. Lebedev, "K vykhodu sobraniia sochinenii Lunacharskogo," Novyi mir, 1965, no. 2, p. 262. 
period of the "cult of personality" the little that Soviet readers learned about Lunacharsky was distorted to fit the character of those years.

Soviet critics were also quick to point out the significance of the Lunacharsky controversy for current policies and problems in the arts. Lebedev, in a monograph on Lunacharsky's aesthetics, maintained that Lunacharsky's aesthetic theories "have, without a doubt, a direct relation to the practical questions of socialist art in the contemporary stage of its development." 3 E. Ermakov, writing in Izvestiia, said that "one cannot overemphasize the role of Lunacharsky ... [ [in working out] the basic interrelationships between the party, the government, and the arts." 4 This view of Lunacharsky's activities in the formulation of basic policies on the arts during the early years of Bolshevik rule is supported by the observation of one of Lunacharsky's contemporaries, Viacheslav Polonsky, who in 1928 asserted: "While Bukharin and Trotsky were passing their judgments on art and literature, Lunacharsky was carrying out its practical work through his personal activities. He personally had to decide on practical matters . . . about the problem of our cultural heritage, about reaching the proletariat, about the revolutionary intelligentsia . . . , about the problems of literature in a proletarian society. . .."s The implication here, of course, is that although Lunacharsky's words and publications may be interpreted in many ways, his deeds and activities must also be assessed. Lebedev made this point clear when he stated that "as a critic he is generally accepted, but views vary on his role as a director of Soviet art."6

Further reflection on Lunacharsky's suitability as a subject for a debate on current policies shows that he had an acute sense of timing in regard to subtle changes in attitudes and atmosphere during the $1920 \mathrm{~s}$, and was able to avoid extreme official censure until his (also timely) natural death in 1933. He cannot, in other words, be grouped easily with former "enemies of the regime" as can Trotsky, Averbakh, and Bukharin, although he had certain connections with all of them. His theories and activities must be judged on their own merits, not dismissed as representative of some clique or faction. Finally, his activities on behalf of the regime in bringing a substantial part of the intelligentsia to the side of the Bolsheviks, his defense of writers, and his strenuous and successful attempts to save historical monuments and traditions from destruction by powerful antihistorical fanatics deserve at least as much p. 143.

3. A. A. Lebedev, Esteticheskie vzgliady A. V. Lunacharskogo (Moscow, 1962),

4. E. Ermakov, "Revoliutsionnyi talant," Izvestiia, May 16, 1967.

5. Viacheslav Polonsky, Ocherki literaturnogo dvisheniia revoliutsionnoi epokhi (Moscow, 1928), p. 183.

6. Lebedev, "K vykhodu sobraniia sochinenii Lunacharskogo," p. 262. 
praise as has traditionally been lavished on Gorky. Thus, criticism of him must stay within certain bounds.

Lunacharsky's career seems on the surface sufficiently diverse to support the views both of those who saw him as a faithful follower of the party line and of those who did not. ${ }^{7}$ His contributions to Marxist literary criticism, to

7. All biographies of Lunacharsky are Soviet publications. The major works of interest in book form include a brief treatment of his activities in P. Lebedev-Poliansky, A. V. Lunacharskii: K 50-letiiu so dnia rozhdeniia (Moscow, 1926) ; A. Khalatova, ed., Pamiati Anatoliia Vasil'evicha Lunacharskogo: Sbornik statei (Moscow, 1935); A. Krivosheeva, Esteticheskie vzgliady A. V. Limacharskogo (Moscow and Leningrad, 1939); P. Bugaenko, A. V. Lunacharskii kak literaturnyi kritik (Saratov, 1960); N. Bychkova and A. Lebedev, Lunacharskii: Pervyi Narkom prosveshcheniia (Moscow, 1960); A. Elkin, A.V. Lunacharskii: Esteticheskie vzgliady, obshchestvenno-literaturnaia $i$ kriticheskaia deiatel'nost' (Moscow, 1961) ; N. A. Samoilova, Lunacharskii: Borets sa sovetskoe iskusstvo (Moscow, 1961); A. A. Lebedev, Esteticheskie vagliady A. V. Lunacharskogo (Moscow, 1962), a serious critical study, perhaps the most liberal interpretation of this group; N. A. Lunacharskaia-Rozenel, Pamiat' serdtsa (Moscow, 1962), first edition of the memoirs of Lunacharsky's second wife, reissued in a larger edition under the same title in 1965; Ia. Rotkevich, A. V. Lunacharskii $i$ ego rol' v sozdanii sovetskoi metodiki prepodavaniia literatury (Kuibyshev, 1962); I. A. Kairov, $A . V$. Lunacharskii: Vydaiushchiisia deiatel' sotsialisticheskogo prosveshchenii (Moscow, 1966); A. Elkin, Lunacharskii (Moscow, 1967), a book in the biography series "Zhizni zamechatel'nykh liudei," which, although it uses numerous quotations, has no footnotes or references. Despite this long list of books on Lunacharsky, none of them deals with his life in any depth or with completeness. Material on Lunacharsky can be found elsewhere, and information about his life is still kept in closed archives in the Soviet Union.

In addition to the volumes mentioned above, important autobiographical sources for Lunacharsky's activities and thoughts are available. A. V. Lunacharskii: Vospominaniia $i$ vpechatleniia (Moscow, 1968) consists of fifty-two complete autobiographical sketches and excerpts from others, one from previously unpublished materials; although most of the selections were published before, many appeared in journals and newspapers that are now scarce. Siluety (Moscow, 1965) is a republication of Lunacharsky's important sketches of Bolshevik leaders, first published in his Velikii perevorot (Moscow, 1919) and Revoliutsionny'e siluety (Moscow and Leningrad, 1923). His war memoirs, Evropa $v$ pliaski smerti (Moscow, 1967), are also in print.

Bibliographies and bibliographical aids for archival materials on and by Lunacharsky indicate that most of his still unpublished materials are in the Central State Archive of Literature and Art (383 pieces), the Institute of Marxism-Leninism (the amount has not been disclosed), the Institute of World Literature of the Academy of Sciences USSR (94 pieces), and the Pushkinskii Dom in Leningrad (36 pieces). For guides to these sources, and to Lunacharsky's published and unpublished correspondence, see especially N. Panchenko, "Avtografy A. V. Lunacharskogo v Pushkinskom Dome," Russkaia literatura, 1966, no. 2, pp. 212-16; K. D. Muratova, ed., Istoriia russkoi literatury kontsa XIX-nachala XX veka: Bibliograficheskii ukazatel' (Moscow, 1963), pp. 289-91 (letters); Tsentral'nyi gosudarstvennyi arkhiv literatury $\mathrm{i}$ iskusstva SSSR, Putevoditel', literatura (Moscow, 1963), pp. 276-79; K. D. Muratova, ed., A. V. Lunacharskii o literature i iskusstvc: Bibliograficheskii ukazatel', 1902-1963 (Leningrad, 1964).

Of the increasing number of articles on Lunacharsky, several include rather large quantities of information based on scholars' findings in materials previously inaccessible in Soviet archives. These materials are coming out, bit by bit, in articles on a wide range of topics. See, for example, N. A. Samoilova, "A. V. Lunacharskii o svobode tvorchestva 
the foundation and establishment of Soviet cultural programs, and to the international stature of the Bolshevik regime were recognized by almost all, including his harshest critics. If the Soviets today were to run a tally on Lunacharsky's positive contributions, it might include the following "pluses." Lunacharsky was an early Marxist. He joined the Russian Social Democratic movement before 1900 and worked with Lenin on several important prerevolutionary Bolshevik journals after 1904. He actively participated in most of the Social Democratic congresses in Europe, established an early reputation as a Marxist art critic, furthered the cause of proletarian revolution, was dedicated to promoting socialism in the Soviet Union, publicly supported the party in most major issues after 1917, and represented the regime at the League of Nations and in foreign capitals in the early 1930s. On the negative side, however, the following points can be listed. He openly followed the theories of the much criticized Mach and Avenarius after 1900, he promoted the "god-building" heresy denounced by Lenin in his Materialism and Empiriocriticism (written in 1908), and he had a leading role in the Vpered splinter group which challenged Lenin's organization of the party from 1908 to 1917. Lunacharsky continued to associate himself with the officially denounced theories of Bogdanov and the Proletkult organization in the early Soviet period. Finally, he pursued permissive policies in regard to artistic experimentation and innovation in the 1920s, and he apparently opposed the gradual strengthening of the party's role in affairs of culture and the arts in the late 1920 s.

The same reasons that make Lunacharsky a useful figure around which to focus a dialogue also make him a difficult subject for Soviet writers to deal with. He was often inconsistent. His actions occasionally contradicted Lenin or the party line. He appeared to be a relatively independent thinker. Artists whom he saved from starvation or official ostracism still harbor nostalgic memories of him. ${ }^{8}$ This has created a "legend of liberalism" (a Soviet phrase)

i partiinosti literatury," in V. V. Novikov et al., eds., Problemy sotsialisticheskogo realizma (Moscow, 1959), pp. 212-62 ; N. A. Trifonov, "Lunacharskii v gorode Lenina," Zvezda, 1965, no. 11, pp. 183-87; and A. V. Koltsov, "Neopublikovannye pis'ma A. V. Lunacharskogo," Vestnik Akadcmii nauk SSSR, 1965, no. 10, pp. 79-85.

Lunacharsky's letters and reminiscences can be found in several places, as noted in the bibliographical guides cited. Among the sources cited are some of the following, included as examples from which about forty documents of this nature can be readily found. In the collections of Lunacharsky's works, see especially $V$ mire muzyki: Stat' $i$ i rechi (Moscow, 1958), A. V. Lunacharskii o kino (Moscow, 1965), and Na Zapade (Moscow, 1927). See also the selections in Ezhegodnik Malogo teatra, 1955-1956 (Moscow, 1961), Leninskii sbornik (Moscow, 1945), Romain Rolland's Sobranie sochinenii (Moscow, 1958), and several volumes of Literaturnoe nasledstvo (Moscow, 1931-).

8. For a recent revelation from archival sources of Lunacharsky's personal intervention on behalf of Aleksei Remizov and S. K. Sologub, arrested by the Cheka in 1919, see Panchenko, "Avtografy A. V. Lunacharskogo v Pushkinskom Dome," p. 215. 
about him. ${ }^{9}$ Lunacharsky is often pictured as the artists' friend in the regime - a talented, liberal administrator who advocated artistic freedom and demonstrated that whenever possible he preferred to judge a work of art on its own terms rather than on purely political ones. Memoir materials currently being published portray Lunacharsky as a person who in his infrequent spare time liked to spend an evening drinking exotic coffee and talking about current literary topics at Nikolai Tikhonov's, listening to string quartets at Maxim Gorky's, or playing billiards with Mayakovsky. ${ }^{10}$

Accompanying this "friend of the artist" image is an attempt by some to portray Lunacharsky as advocating the independence of art from the party. ${ }^{11}$ Those who view Lunacharsky in this light claim that he consistently advocated "official" neutrality toward the arts. Kornei Chukovsky, in his memoirs of the early Soviet years, supports this interpretation, and claims that "one never heard an authoritarian note in Lunacharsky's voice." ${ }^{\prime 2}$ A. Metchenko, writing in the early 1950s, complained that Lunacharsky practiced "the principle of broad neutrality ... . in respect to the complete noninterference of the party of the proletariat into the business of ideology ... and into the sphere of art."'13

The regime has followed the reinterpretations of Lunacharsky and is aware of the legends that have currently grown up around him. The political leaders realize that legends and reinterpretations can be used to press for greater artistic freedom, and have taken steps to ensure that discussion will proceed according to the rules of the game. Although the regime could halt the arguments at any time, it has chosen to deal with the situation by entering into the debate. Providing ample ammunition for examination of the views and activities of Lunacharsky, the government has authorized the publication in new scholarly editions of the greater part of Lunacharsky's previously published and unpublished works, which deal with a wide variety of topics. ${ }^{14}$

9. For a brief discussion concerning the "legend" of Lunacharsky, see the excellent review by Sheila Fitzpatrick, "A. V. Lunacharsky: Recent Soviet Interpretations and Republications," Soviet Studies, 18, no. 3 (January 1967):270-71. In this article Miss Fitzpatrick, whose conclusions are quite the opposite of mine, asserts that Lunacharsky's liberalism had no basis in fact and therefore he is a poor subject for the advocates of liberal measures in the arts to choose as their champion.

10. For this point of view see, for example, Kornei Chukovsky, Iz vospominanii (Moscow, 1959), pp. 421-22, 430; Natalia Lunacharskaia-Rozenel, Pamiat' serdtsa (Moscow, 1962), pp. 37-38; and A. Iablochkina, 75 let v teatre (Moscow, 1958), p. 253.

11. For a discussion of this see Samoilova, "A. V. Lunacharskii o svobode tvorchestva i partiinosti literatury," p. 227. Samoilova takes a strongly negative view of his more liberal policies.

12. Chukovsky, Iz vospominanii, p. 423.

13. A. Metchenko, Tvorchestvo Maiakovskogo, 1917-1924 gg. (Moscow, 1954), pp. 503 ff.

14. Sheila Fitzpatrick, in the article cited in note 9, reviews some of these publications in editions up to 1967 . Of further bibliographical note are the following collections 
In most cases (there are some significant exceptions) the new editions contain lengthy introductions and annotations setting forth elaborate interpretations of their place in the development of the USSR. In the introduction to Lunacharsky's contributions to theater criticism (volume 3 of his Sobranie sochineniia), for example, the reviewer debunked the legend of Lunacharsky's liberalism, claiming that it was a myth, and that it had its origins in vicious rumors spread by the enemies of Lunacharsky and of the state, the RAPP group. ${ }^{15}$

In addition to publishing explanatory introductions and annotations, the regime has entered the debate by commenting in the official press on the publication of Lunacharsky's works. The eight-volume Collected Works of Lunacharsky, for example, were commented on in Izvestiia and Kommunist when publication of the Works was begun and when it was completed. ${ }^{16}$ These review articles, as will be shown later, by putting forth a narrowly conservative (and semiofficial) view, attempted to keep the dispute within proper bounds and to deflect comment from incendiary topics, such as party neutrality in art and complete artistic freedom of expression. This attempt to control discussion, however, was not successful.

The dispute over Lunacharsky in the periodical press had a lively beginning in 1958, after the appearance of four rather unimportant articles on Lunacharsky in 1956 and 1957. N. A. Glagolev, in a lengthy and important article in the semiofficial publication Scholarly Papers of the Academy of the Social Sciences, stated: "[Lunacharsky's] varied activities and strong merits in the history of Russian literary criticism are still far from being fully recognized ... [and] have not yet received a fair and thorough evaluation."17

and guides: Valerian Polonsky, A. V. Lunacharskii: Bibliograficheskii ocherk (Moscow, 1926) ; R. Mandelshtam, Knigi A. V. Lunacharskogo (Moscow and Leningrad, 1926); B. I. Kozmin, Pisateli sovremennoi epokhi, vol. 1 (Moscow, 1928); N. K. Piksanov, Marksistskoe iskusstvovedenie (Moscow and Leningrad, 1929); Zapiski ob uchenykh trudakh deistvitel'nykh chlenov Akademii nauk SSSR, izbrannykh 1 fevralia, 1930 goda (Leningrad, 1930) ; V. V. Gura, Russkie pisateli v Vologodskoi oblasti (Vologda, 1951); N. A. Samoilova, "Bibliografiia knig i statei A. V. Lunacharskogo, izdannylkh posle 1917 g.," in Akademiia obshchestvennykh nauk pri TsK KPSS, Ucheny'e zapiski, 39 (1958) : 332-56; V. Lantsuzsky, "Bibliografiia knig i statei A. V. Lunacharskogo," in Zapiski Karshinskogo pedagogicheskogo instituta, 5 (1961):75-85; Muratova, A. V. Lunacharskii o literature $i$ iskusstve. See also the bibliographical listings and commentaries in the collection of Lunacharsky's works, Sobranic sochinenii $v$ vos'mi tomakh: Literaturovedenie, kritika, estetika (Moscow, 1963-67).

15. Deich, in Lunacharsky, Sobranie sochinenii, 3: 518.

16. "Ob otnoshenii literaturnomu naslediiu A. V. Lunacharskogo," Kommunist, 1962, no. 10, and E. Ermakov, in Izvestiia, May 16, 1967.

17. N. A. Glagolev, "A. V. Lunacharskii i nekotorye voprosy razvitiia russkoi literatury," in Akademiia obshchestvennykh nauk pri TsK KPSS, Uchenye sapiski, 35 (1958): 53 . 
The ensuing discussion in the periodical press covered many issues, but the most important and fully discussed were the following: Lunacharsky's ideological credentials (specifically, how faithful was he to Marxism-Leninism?), the relationship of the party to art and the artists, and the question of freedom of artistic expression.

Perhaps the most sensitive issue was the evaluation of Lunacharsky's position on the role of the party and the state in the arts. In a publication of the party's Higher School, N. A. Samoilova used previously unpublished archival materials to criticize some of Lunacharsky's statements on this subject. She said, for example, that in articles written in 1924 Lunacharsky had said "I have always stood and still stand on the point of view that government regulation of art is a harmful thing" and had claimed that art was a phenomenon "outside of the realm of the state" (vnegosudarstvennoe). ${ }^{18}$ Samoilova deplored this point of view, calling it "entirely . . . contradictory to the policy of state and party in the regulation of art." She considered Lunacharsky's position "mistaken and harmful" and attributed it to the influence of neoKantian ideas he acquired before the revolution. ${ }^{19}$ Other writers, however, took a different point of view. A. A. Lebedev quoted Lunacharsky as saying, "In questions of form and style the taste of the People's Commissar and all representatives of [political] power must not be included...." This statement does not deal specifically with interference or noninterference, but a few lines later Lebedev commented: "Lunacharsky clearly understood that art cannot arise through force. . . . A leadership that uses force and not persuasion is pernicious. ... It is unfortunate that some time ago we witnessed a complete disregard for the autonomous role of talent in artistic creativity."20

Other writers addressing themselves to this topic only further demonstrated the lack of agreement on Lunacharsky's position. In 1967 Izvestiia, in a review of Lunacharsky's Collected Works, quoted him out of context and without reference as having stated that "the principles of the party's policy in the arts were never noninterference in artistic life."21 The Communist Party's theoretical journal, Kommunist, in an article that appeared before the Collected Works were published, claimed that Lunacharsky had made several mistakes and that Lenin and the party had attempted to correct them. ${ }^{22}$ The inference to be drawn, however, is either that the party made mistakes in this area or that it was unable to maintain discipline. Finally, Glagolev, apparently

18. The reference here is to Lunacharsky's collection of essays, Iskusstvo i revoliutsiia (Moscow, 1924), p. 6.

19. Samoilova, "A. V. Lunacharskii o svobode tvorchestva i partiinosti literatury," pp. 228-29.

20. Lebedev, "K vykhodu sobraniia sochinenii Lunacharskogo," p. 263.

21. Ermakov, in Izvestiia, May 16, 1967.

22. Kommunist, 1962 , no. 10 , p. 33. 
trying to rescue Lunacharsky's reputation, only muddied the water by maintaining that whenever Lunacharsky had disagreed with Lenin, the disagreement was always over tactics; on basic principles they were in firm agreement. ${ }^{23}$

Second in importance only to the political control of art is the related principle of freedom of artistic expression. None of the disputants denied Lunacharsky's support of innovation and variation in art, but attitudes toward his position varied greatly. Kommunist, in the 1962 article cited above, took a very dim view of Lunacharsky's "defense of the cultural nihilists (Proletkult) and his outspoken praise of the Futurists" and claimed that Lunacharsky, because of his questionable ideological past (the influence of Avenarius, Mach, Bogdanov, and even Plekhanov!) "seriously misinterpreted many writers and artists who dabbled in artistic experimentation."24 Samoilova denied Lunacharsky's connection with "abstract freedom" in art. She cited undated archival sources, not previously published, to assert that Lunacharsky did not truly believe in total freedom of artistic expression but only in freedom in connection with the basic aims and goals of the proletariat as defined by the party. In their short biography of Lunacharsky, Bychkova and Lebedev struck a balance on this issue but bared both horns of the dilemma when they stated, "Lunacharsky always supported artistic innovation because he cared for the growth and development of Soviet culture . . . , but he was always opposed to modernistic formalists . . . always criticized art for art's sake."25

Other writers, however, applauded Lunacharsky's views on innovation and set forth their interpretation of his stand on artistic freedom. Some called for a broader framework for judgment of Lunacharsky's stand and therefore a broader framework for judgment of contemporary Soviet art as well. In his book on Lunacharsky's aesthetics Lebedev was clearly appealing for more than a liberal interpretation of Lunacharsky's views alone when he said: "Aesthetics touches artistic creativity in all fields. ... It must draw from the sum total of all knowledge, and must not exclude any discipline-engineering, biology, psychology, etc. . . . It is the merit of Lunacharsky, in our view, that he posed the question of the necessity of bringing these disciplines to bear not only on criticism, but to the direct analysis of the phenomenon of art itself." ${ }^{26}$ Lebedev even spoke favorably of Lunacharsky's un-Marxist predilection for the intuitive, subconscious element in artistic creativity, a position harshly condemned by others. ${ }^{27}$

23. Glagolev, "A. V. Lunacharskii i nekotorye voprosy . . ," p. 56.

24. Kommunist, 1962, no. 10, pp. 36-37. For this same view but in greater detail, see I. Ivanov, Formirovanie ideinogo edinstva v sovetskoi literature, 1917-1932 (Moscow, 1960), pp. $115 \mathrm{ff}$.

25. Samoilova, "A. V. Lunacharskii o svobode tvorchestva i partiinosti literatury," pp. 237-39. Bychkova and Lebedev, Lunacharskii, pp. 28-29.

26. Lebedev, Esteticheskie vagliady, p. 185.

27. Glagolev, "A. V. Lunacharskii i nekotorye voprosy ..., " p. 55. 
Two other writers, N. Gei and V. Piksanov, in a thoughtful article written in 1967, ranked Lunacharsky with the eminent NEP literary critic Alexander Voronsky on the matter of freedom of artistic expression. The writers asserted that both men thought that all art must be measured as broadly as possible, partly because they believed in the eventual synthesis of all styles and expressions. $^{28}$ To illustrate Lunacharsky's liberal attitude toward innovation and experimentation, Gei and Piksanov quoted him as saying: "The writer must never simply quote slogans from the party. No, he is a pioneer-experimenter." 29 In an article in Novyi mir in 1966 two Soviet critics maintained that although "Lunacharsky considered formalism and pseudo innovation a very serious sickness of the young Soviet art," he nonetheless never condemned it out of hand, but rather used the criteria of "realism (broadly defined), promise of talent, or serious intent." 30 These writers claimed that Lunacharsky was never dogmatic or doctrinaire in his artistic judgment but held to a true dialectical position. Lunacharsky "was far from presenting socialist realism as a ceiling of immovable rules and dogma. He conceived it [realism] as a principle or method, leaving art the very broadest possibilities, supposing many-sided forms, styles, genres ..." (p. 228). In a plea for a flexible interpretation of artistic creativity, another critic pointed out that "Lunacharsky's aesthetics and his criteria for art were based on ... the real success of our art. . ." 31 This statement, of course, could also easily be attributed to Voronsky or Trotsky, who often said that the sole criterion for art was "Is it good or is it not?"

Many who opposed this liberal interpretation of Lunacharsky employed the tactic of maligning his character-for example, by calling into question his Marxism-Leninism. Citing his prerevolutionary intellectual development, Samoilova suggested that his wanderings from the Marxist fold in his infatuation with Mach and Avenarius, his period of "god-building," his connection with $V$ pered, and his connections with Bogdanov had a negative effect on his philosophical position, even during his post-1917 career. Another writer pointed out to his readers that "Lunacharsky's individual utterances" were too often identified as Lenin's own views, but that in reality "their fundamental positions were different in matters of ideology and art." Ermakov, however, although he acknowledged the seriousness of Lunacharsky's prerevolutionary wanderings and admitted that there were differences between

28. N. Gei and V. Piksunov, "U istokov marksistskoi literaturnoi kritiki," Voprosy literatury, 1967, no. 8, pp. 145-47. (This point of view, of course, is exactly the same as Trotsky's, so forcefully brought forth in his 1923 publication of Literature and Revolution.)

29. Ibid., p. 151.

30. A. Dementiev and I. Sats, “A. V. Lunacharskii i sovetskaia literatura," Novyi mir, 1966, no. 12, p. 226.

31. Lebedev, Esteticheskie vagliady, p. 132. 
Lenin and Lunacharsky after the revolution, maintained that Lenin and the party successfully corrected his sometimes mistaken positions on ideological matters. $^{32}$

Other writers, however, opposed any attempt to sidetrack the debate from vital areas of interest to the artist or to call into question the validity of Lunacharsky's viewpoints by questioning his ideological credentials. ${ }^{33}$ Dementiev and Sats forcefully proclaimed: "In previous biographies, some writers only talk about his 'Machist period' or his 'god-building period.' . . . There were no such periods. . . . No work has been done to show the progressive aspect of his work at this time. We must remember that Lenin always pointed out that it is through a man's works that he should be judged ... even though his ideology is not pure." ${ }^{34}$ Several scholars thus attempted to show Lunacharsky's value to the prerevolutionary Bolshevik organization, his work with Lenin, his activities as an orator and revolutionary propagandist, his original contributions to Marxist theories of art and literary criticism, and his importance at the Social Democratic congresses at Stockholm and Stuttgart. ${ }^{35} \mathrm{~S}$. Malakhov presents this approach in his article on Lunacharsky in the important Soviet collection, History of Russian Criticism: "Despite his mistakes, the prerevolutionary Lunacharsky wrote in the spirit of revolutionary Marxism, in the best tradition of aesthetics and literary criticism of the Russian revolutionary democrats ... Olminsky and Vorovsky. ... The philosophical errors and political mistakes did not make a negative impression on his objective cognition and on the ideological-educational strength of his literary and artistic criticism." 36

The issues discussed above are by no means the only ones taken up in the Lunacharsky controversy of the past decade. Other subjects not touched on here include his anti-Lenin position on the question of the autonomy of Proletkult in 1920, his part in the debate over the possibility of creating a proletarian culture, his role in the formulation of policy on the arts in the 1920s, the occasional inconsistency between his public statements and his

32. Samoilova, "A. V. Lunacharskii o svobode tvorchestva i partinosti literatury," p. 214. V. Shleev, "Iz istorii bor'by za partiinost' iskusstva," in Voprosy iskusstva v svete bor'by ideologii: Sbornik statei (Moscow, 1966), p. 28. Ermakov, in Izvestiia, May 16, 1967.

33. See, for example, the approaches of Elkin in his Lunacharskii, Ivanov in Formirovanie ideinogo edinstva, and Krivosheeva in Esteticheskie vigliady.

34. Dementiev and Sats, "A. V. Lunacharskii i sovetskaia literatura," pp. 213-14.

35. See, for example, N. A. Trifonov, "Lunacharskii v gorode Lenina," Zvesda, 1965, no. 11, pp. 183-87; A. L. Kublanov, "O voennorabote A. V. Lunacharskogo," Istoriia SSSR, 1965, no. 5, pp. 119-26; N. Bychkova and A. Tsvetkova, "Anatolii Vasil'evich Lunacharskii," Voprosy istorii KPSS, 1965, no. 11, pp. 121-24; and Lebedev, Esteticheskie vzgliady, pp. $54 \mathrm{ff}$.

36. S. Malakhov, "A. V. Lunacharskii," in Istoriia russkoi kritiki, 3 vols. (Moscow, 1958-64), 2 : 595-96. 
action, and his "humanism," a topic of considerable interest in Soviet Marxism today. But perhaps the preceding review of some of the issues will serve to illustrate the technique and style of the dialogue on fundamental problems in the arts as expressed through the Lunacharsky debate. It is clear that the discussion was more or less "set up" and that the regime was interested in allowing considerable freedom in discussion. Which side has the strongest hand in terms of what is known about Lunacharsky? Although the dossier of material on and by Lunacharsky is less than complete, such an assessment can and should be made.

An examination of Lunacharsky's activities, published speeches, reminiscences, letters, and articles during the 1920s reveals that those who have attempted to build on the legend of Lunacharsky's liberalism have a very strong case. A great deal of what Lunacharsky said and did during this period can be effectively used to advance the position of those who wish to liberalize the regime's policies on the arts.

During the 1920s it was possible for a rather free exchange of ideas to occur, and opinions on art and culture were varied and contradictory. As Lunacharsky stated to an audience gathered to view the Eighth Exhibition of the Association of the Artists of Revolutionary Russia (AKhRR): "We are building diversity now. We know that the edifice of culture must be built with many sides, simultaneously, and in various stages. This must be done so that some day the great plan of building socialism will be fulfilled." ${ }^{37}$ This situation existed partly because at that time the Bolsheviks had not yet attained unanimity on basic principles even within the party, not to mention society as a whole. ${ }^{38}$

The way Lunacharsky analyzed Soviet society during the 1920s was, on the whole, similar to the way Bukharin saw it when he promoted the principle of "free anarchic competition" at the Fourteenth Party Congress in $1925 .^{39}$ As a result, Lunacharsky's own basis for supporting a literary or artistic group was very broad. With the exception of admitted counterrevolutionaries or outright saboteurs, Lunacharsky encouraged artists of almost all political positions if he felt their motives were sincere, if they had recognized

37. "Rech' na otkrytii VIII vystavki AKhRR," in VIII Vystavka AKhRR: Zhizn' $i$ byt narodov SSSR (Moscow, 1926), p. 2.

38. For an excellent treatment of this situation, see S. V. Utechin, "The Bolsheviks and Their Allies After 1917: The Ideological Patterns," Soviet Studies, 10, no. 2 (October 1958) : 113-25.

39. For a good summary of Lunacharsky's views on the NEP programs, see his "Novaia ekonomicheskaia politika i NKP" (1921), in A. V. Lunacharskii o narodnom obrazovanii (Moscow, 1958), p. 189. It was originally published in a collection of Lunacharsky's articles, Problemy narodnogo obrazovaniia (Moscow, 1925), pp. 198-204. 
talent, and if they expressed lofty moral and ethical sentiments. ${ }^{40}$ His rejection of a writer or his works in most cases had less to do with his class background, closeness to the party line, or avowed political position vis-à-vis the Bolsheviks, than it did with the work itself. Lunacharsky's support of the socalled fellow travelers is a good example of his attitude on this question. As he stated to the All-Union Conference of Proletarian Writers (VAPP), the group most hostile to the fellow travelers: "Why should we not throw aside the fellow travelers? Because they sometimes produce highly artistic work, excellently reflecting the attitude of the masses. What do you want to do with them? Shut them up? Strangle them? Certainly not! Their works should be read, but at the same time our Marxist criticism should parallel any harmful tendencies that they might contain." ${ }^{31}$

There are several explanations for Lunacharsky's inclusive attitude toward the arts at this time. Among them was his firm commitment, as commissar of education, to bring the artists and the masses closer together. ${ }^{42}$ Everything that contributed to this goal in the area of culture was to be promoted and supported, including works of art by those openly critical of the regime. In his opinion, debate among all groups in the world of art was desirable because it forced Marxists to come up with definite answers. ${ }^{43}$ Lunacharsky thought that the classics of Marxism had little to say specifically about problems of art in society and that Soviet attempts to formulate guidelines in this area were still in a very tenuous and exploratory stage. Another reason for Lunacharsky's liberal attitude toward divergent points of view was his conviction, also shared by Bukharin, ${ }^{44}$ Trotsky, and Voronsky, that to exclude controversial artistic groups by administrative fiat could only work to the detriment of art and society as a whole. The young Soviet society needed all

40. Lunacharsky's support and praise of many writers who have been out of favor in official literary and art circles for decades is one of the most important things brought out in the memoirs of his wife, Natalia Lunacharskaia-Rozenel (see note 7).

41. "Puti sovremennoi literatury," in Lunacharsky, Sobranie sochinenii, 2:280; originally published in Zvezda, 1925, no. 1. The term poputchiki (fellow travelers), apparently coined by Trotsky, was applied during the period to. writers who were not Communists but refused to engage themselves politically either for or against the party.

42. Speech of Lunacharsky to the Executive Committee of the Congress of Soviets, in Narodnoe prosveshchenie $v$ RSFSR $k$ 1927/28 uchebnomu godu (Moscow, 1928), pp. 175-76.

43. "Formalizm v nauke ob iskusstve," in Pechat" i revoliutsiia, 1924, no. 5, p. 11. Lunacharsky did, however, criticize the formalists for a great many of their principles, assertions, and theories.

44. Bukharin in 1925 was quite adamant about rejecting groups that sought exclusive support of the party or claimed a monopoly on truth, style, and so forth. See especially his article, "Proletariat i voprosy khudozhestvennoi politiky," Krasnaia nov", 1925, no. 4, pp. 271-72. The journal's editor, Alexander Voronsky, held the same view and published the work of writers with a wide variety of viewpoints. See Robert A. Maguire, Red Virgin Soil: Soviet Literature in the 1920's (Princeton, 1968). 
the talent it could muster. In addition, as Lunacharsky demonstrated through his personal activities, he believed it was desirable that persons with talent should come to support the Bolshevik regime by their own conviction, and that Soviet cultural policy should be directed toward this goal. ${ }^{45}$

Another reason for Lunacharsky's permissive attitude was his conception of the artist. In Lunacharsky's world view there was a place for the "hero" in history, and his greatest hero was the artist. Believing that individuals are not simply objects of history, Lunacharsky asserted that man is an active force in the historical process, that he can plan, build, and change his society. ${ }^{46}$ The artist possesses special faculties that enable him to penetrate more deeply than others into human existence. ${ }^{47}$ An artist may or may not possess political and social awareness, but in spite of himself he plays a part in the development of political ideas because "as an artist, he formulates his own experiences by laws other than those that the journalist or publicist might follow."48 Departing from the basically "mechanistic" views of Bukharin and the Marxist literary critic V. Friche on this question, ${ }^{49}$ Lunacharsky believed that the artist acts as more than a mirror of life. Through his works the artist is able to organize social forces into meaningful and intelligible patterns and to inspire man to great heights of activity. Lunacharsky's view of the hero in history, the artist as inspirer and mover of society, may explain why some contemporary Soviet critics claim that "No one in the twentieth century, except, perhaps, V. I. Lenin and M. Gorky, equaled [Lunacharsky's] . . . importance in working out the bases of . . socialist realism." 50

From this view of the artist, Lunacharsky drew the logical conclusion that interference with an artist's exceptional powers might impair his vision. Going even further, Lunacharsky asserted that the artist needed special attention and the sympathy and understanding of his society. In an emotional piece composed after the tragic suicide of Vladimir Mayakovsky in 1930, Lunacharsky wrote: "Not all of us can be like Karl Marx when he said that poets need a great deal of sympathy, gentle kindness, and understanding. Not all of us

45. Narodnoe prosveshchenie v RSFSR, pp. 175-76.

46. Meshchanstvo $i$ individualizm: Sbornik statei (Moscow and Petrograd, 1923), p. 24. Originally published in 1909 under the same title, it was republished in 1923 with a foreword in which Lunacharsky stated that his ideas were still valid.

47. Besedy po marksistskomu mirosozertsaniiu (Leningrad, 1924), pp. 68-69.

48. Voprosy kul'tury pri diktature proletariata (Moscow and Leningrad, 1925), pp. $115-16$.

49. Robert Maguire, in Red Virgin Soil (pp. 255 ff.), discusses the aesthetic position of Bukharin and Friche, who he claims supported the theory of "mechanism." He says that Lunacharsky and others followed the theory of "dialectism."

50. I. Anisimov, N. F. Belchikov, et al., "Predislovie," in Lunacharsky, Sobranie sochinenii, 1 : xxvi. 
remembered this, and not all of us realized that Mayakovsky needed an enormous amount of this kindness." 51

Lunacharsky stated these views publicly on many occasions. Particularly noteworthy is the statement he made when the important 1925 Central Committee resolution on belles-lettres was set forth in Pravda on July 1, 1925.52 The decree has been variously interpreted for decades either as a liberal statement allowing the arts freedom from interference by the regime or as one that granted the principle of party interference at will. ${ }^{33}$ Lunacharsky's interpretation of the decree, which he had a major part in formulating, was that it insured equal support by the party for all literary groups without interference in the productivity of any. ${ }^{54}$ Lunacharsky's interpretation of the decree was the same as Bukharin's.

Lunacharsky's views on the question of the party-state relationship to independent groups of artists was also set forth in 1920, when he came into conflict with Lenin over the issue of the autonomy of Proletkult, a broadly based organization formed to promote proletarian culture and to educate the workers in ideology and the arts. Lenin suspected the organization of harboring intellectuals with philosophies not in tune with his own, and he feared that their organizational successes could lead to the creation of an independent power base. As a result, he decided in 1920 to order that Proletkult be incorporated into the Commissariat of Education so that it could be watched and controlled. Lunacharsky openly opposed this measure because of his sympathy for the autonomous existence of Proletkult's activities. As he stated: "In 1917 when I attended the conference on Proletkult activities . . . II saw

51. "Vladimir Maiakovskii-novator," in Lunacharsky, Stat'i o literature (Moscow, 1957), p. 405; originally published in Literatura $i$ iskusstvo, 1931, no. 5-6. For an interesting account of Lunacharsky's personal relations with Mayakovsky, see "Lunacharskii i Maiakovskii," in Lunacharskaia-Rozenel, Pamiat" serdtsa (1965), pp. 24-53.

52. For a full English translation of this resolution, see E. J. Brown, The Proletarian Episode in Soviet Literature, 1928-1932 (New York, 1953), pp. 235-40.

53. There has been considerable debate over the interpretation of this decree among Soviet and non-Soviet scholars. Herman Ermolaev, in his "Soviet Literary Theories, 1917-1934: The Genesis of Socialist Realism," University of California Publications in Modern Philology, 69 (1963): 46-54, maintains that this decree in fact indicated party decision to intervene in the arts; whereas the historian E. H. Carr, in his Socialism in One Country, 1924-1926, vol. 2 (London, 1959), p. 81, declared that in this and other resolutions of the period the party's stance was one of necessary neutrality. Samoilova, in her "A. V. Lunacharskii o svobode tvorchestva i partiinosti literatury," p. 227, claims that any interpretation which states or implies party noninterference is "incorrect" and "un-Marxist." Dementiev and Sats, in their article on Lunacharsky in Novyi mir, 1966, no. 12 , p. 220 , assert that party noninterference is clearly stated and implied in the decree.

54. Lunacharsky, "Po povodu rezoliutsii TsK o literaturnoi politike," Novaia vecherniaia gazeta (Leningrad), July 11, 1925, p. 2. 
its value] in the task of raising the intelligence, ethics, and aesthetics of the proletariat, in its independent activity, working out its own proletarian norms ... I began to promote a parallelism: the party in politics, the unions in economics, and Proletkult in culture" (italics added). ${ }^{55}$

In October 1920 Lenin sent a note to the Proletkult conference insisting that it vote to be incorporated into the Commissariat of Education. Depending on Lunacharsky to convey the message and to argue for the adoption of his motion, Lenin was angered when Lunacharsky argued against the motion: "From the October 8th number of Izvestiia it is apparent that at the Proletkult session Comr. Lunacharsky said the exact opposite of that on which we agreed yesterday. ${ }^{, 56}$ Lenin forced the motion to incorporate through the Central Committee of the party, and had it sent to the Proletkult congress in the form of an open letter. ${ }^{57}$ Lunacharsky acquiesced, but in 1924 he made the following interesting statement concerning that letter to Proletkult: "In spite of the fact that I believe that our Central Committee never makes a mistake, I was bold enough to affirm that this letter to Proletkult was too ruthless. I pointed out later to Lenin that if we began such persecution and declared war on the whole camp, which included Futurists, we would spoil many of the achievements we had accomplished." 58

Despite his statements about the autonomy of art, Lunacharsky fully acknowledged the need to guide it occasionally. He therefore found himself in a philosophical dilemma. He also realized that in the Soviet Union any guidance must ultimately come from the party. Yet a careful reading of his statements, written works, and correspondence reveals that he wished to set some kind of limit on party guidance. For example, in a 1921 party congress debate regarding the problems of party-state direction of education and propaganda, Lunacharsky spoke of the difficulty of formulating precise delimitations between party and state functions. He maintained that since the party's goal was to see the spirit of communism envelop the land, the party "must permeate the society as the Bible is permeated with God." ${ }^{50}$ He proposed that a member of the Central Committee be attached to every important

55. "Proletkul't i sovetskaia kul'turnaia rabota," in Proletarskaia kul'tura, 1919, no. 7-8, p. 1.

56. For a copy of this reprimand, see V. I. Lenin, Sochineniia, 4th ed. (Moscow, 1941-62), 31:291-92.

57. The letter to Proletkult was printed in Pravda, Dec. 1, 1920. For a discussion of this affair, see V. V. Gorbunov, "Bor'ba V. I. Lenin s separaticheskami ustremleniiami proletkul'ta," Voprosy istorii KPSS, 1958, no. 1, pp. 33-34.

58. "Osnovy teatral'noi politiki Sovetskoi vlasti," in Lunacharsky, Sobranie sochinenii, $3: 268$. This piece was originally published in 1926 in a pamphlet bearing the same title. Lunacharsky's reference to the Futurists concerns Lenin's harsh statements against them -statements which were also included in the letter to Proletkult.

59. Institut Marksizma-Leninizma pri TsK KPSS, Desiatyi s"ezd RKP (b), mart 1921: Stenograficheskii otchet (Moscow, 1963), p. 154. 
central state institution (such as the Commissariat of Education). But he was quick to point out that a prime function of the state apparatus was to carry out directives from the party, and here "responsible authority must be delegated to the state apparatus." on many important issues the party "must not use the government apparatus directly," but the apparatus must be thought of as a professional body of independent workers helping the society to run in a smooth and effective manner. ${ }^{61}$ At a theater conference held in 1927 he asserted that the government must take a neutral attitude toward artistic style and method, and stated that the reason for the success of the Soviet theater during NEP was the lack of direct party interference. The statement was not received with enthusiasm by some party members in the audience. ${ }^{62}$

These and other statements indicate that although Lunacharsky faced opposition on some of his positions, his views on the party's interference in the arts remained unchanged during his tenure as commissar of education (1917-1929). He was able to say in 1926 that his views on the party and the arts had been gradually supported "by nearly everybody" after $1920 .^{63}$

Some Soviet and non-Soviet writers claim that a significant factor in analyzing Lunacharsky's position during the Soviet period is a change that he underwent in his position on various subjects between 1917 and 1933. It is true that on many issues Lunacharsky's views were not exactly the same in 1933 as they were in 1917. For example, he toned down his earlier ardent support of Proletkult, took a stronger position in favor of art serving the main goals of Soviet society (building socialism), and was less tolerant toward the fringes of artistic experimentation. Soviet works often quote Lunacharsky's writings from 1928 on to make a case for his convergence toward a more orthodox and rigid position on art and literature in the Soviet Union. ${ }^{64}$ It seems to me, however, that this is misleading and distorts Lunacharsky's basic ideas and position. Certainly his views changed during the sixteen years under consideration, but it does not appear that on fundamental issues such as the party's relationship to the arts, the concept of freedom of

60. A Soviet scholar, V. Shleev, writing in the collection Voprosy iskusstva v svete bor'by ideologii (1966), pp. 30-31, suggests that Lenin was unhappy with Lunacharsky's ideas on the autonomy of art and that in 1921 he therefore appointed Krupskaia to head Glavpolitprosovet (a committee within the Commissariat of Education), part of whose function was to promote the "spirit of communism" in the arts.

61. "Zadachi partii na tret'em fronte" (1923), in A.V. Lunacharskii o narodnom obrazovanii (Moscow, 1958), p. 232; originally published in the collection Lenin o prosveshchenii (Moscow, 1924). See also Desiatyi s"ezd RKP (b), p. 170.

62. N. Krylov, ed., Puti razvitiia teatra (Moscow, 1927), pp. 19 ff.

63. "Osnovy teatral'noi politiki Sovetskoi vlasti," p. 268.

64. In this context the works most frequently cited are his "Lenin i literaturovedenie," in Literaturnaia entsiklopediia (Moscow, 1929-39), vol. 6, and "Tezisy o zadachakh marksistskoi kritiki," Novyi mir, 1928, no. 6. 
artistic expression, censorship, monopoly by any one theory of artistic criticism or creativity, and so forth, that Lunacharsky made any kind of volte-face in the latter years of his life.

In Lunacharsky's own words in his memoirs, he began after 1928 to systematize and record for posterity the bases of Russian and Soviet Marxist criticism and aesthetics. But one need not assume that he agreed completely with all the views of those about whom he wrote extensive tracts at this time, as the Soviets assert when they selectively quote from, for example, Lunacharsky's writings on Lenin's harshest views on the arts. One need only point to works by Lunacharsky such as "Sotsiologicheskie i patologicheskie faktory v istorii iskusstva," "G. V. Plekhanov kak literaturnyi kritik," and his introduction to Stefan Zweig's Sobranie sochinenii to demonstrate that his independent thinking and outspoken unorthodoxy did not abate during his later years. ${ }^{65}$

Another important issue involving Lunacharsky is the question of censorship. Lunacharsky was critical of the broad application of censorship, and his administrative position enabled him to act on his beliefs. Although he admitted that some limitations on freedom were necessary because of the real dangers of counterrevolutionary activities and propaganda, his statements almost always minimized the necessity for censorship. As he pointed out to some of the more militant Communists: "The Commissariat of Education [which housed censorship bodies] will of course exercise a degree of political censorship, and delete elements blatantly counterrevolutionary, but it will also fight with great energy those few warriors who bend their bows to shoot down everyone who works even slightly against their wishes." ${ }^{\prime 60}$ According to Lunacharsky the best censorship policy was to employ a light hand and to make certain that those who used the tools of censorship had an understanding of the aims and values of culture. They must be able to "separate the honey from the poison."

In making his case for a limited use of censorship Lunacharsky often expressed the fear that crudely applied censorship would drive artists away from Marxism or into opposition to it. He asserted that if any censorship was to be applied, only educated men of sensitive taste should push the blue pencils, and then only sparingly. Addressing himself to party officials, he said on one occasion: "I think it would be very poor to solve our problems in literature with a Marxist censor. Such a phenomenon creates an aura of suspicion ... we will lose their [the artists'] talent and they will become a force hostile to us." ${ }^{87}$

65. "Sotsiologicheskie $\mathrm{i}$ patologicheskie faktory $\mathrm{v}$ istorii iskusstva," Vestnik Kommunisticheskoi akademii, 1930, no. 37-38; "G. V. Plekhanov kak literaturnyi kritik," Sobranie sochinenii, vol. 8 (first written in 1929-30 but not released in full until its publication in 1967); Stefan Zweig, Sobranie sochinenii, vol. 10 (Leningrad, 1932).

66. "Svoboda knigi i revoliutsiia," in Pechat' i revoliutsiia, 1921, no. 1, p. 9.

67. Voprosy kul'tury pri diktature proletariata, p. 118. 
Lunacharsky usually defended works of art that had redeeming social or aesthetic importance, even though they might be considered "harmful." On several occasions he took issue with the Commissariat of Education's Main Repertorial Committee (Glavrepertkom), which housed the most important censorship body during the NEP. ${ }^{68}$ The committee was made up of members of the Commissariat's Political Education Commission, the People's Commissariat of the Interior (NKVD), and the Literature Section of the Commissariat of Education. It had the right to approve or disapprove all drama, music, and cinema for public presentation, and also passed on newly written works. It could close down any organization that did not comply with its demands.

This body was not an all-encompassing censorship body in practice, largely because its structure and personnel could not handle the great amount of material being written, but occasionally it did clamp down on new works and performances. Lunacharsky personally intervened in its operations several times. He had the opportunity to do this because the Main Repertorial Committee was subject to review and veto by the controlling Collegium of the Commissariat of Education, in which Lunacharsky was the presiding and most influential member.60

In 1924 Lunacharsky threatened the Main Repertorial Committee even before it reviewed the Georgian film Three Lives, produced by I. Perestriani. Lunacharsky had seen the film and thought it artistically the best Soviet film to date. But because it included stories based on Great Russian cruelties toward native Georgians in the nineteenth century and portrayed realistically the harshness of contemporary peasant life in Georgia, Lunacharsky thought that the Main Repertorial Committee might prevent its circulation. A week before the committee was to review the film, he sent a letter to the committee and to the whole Commissariat of Education, praising the film highly and stating: "In the event that the Repertorial Committee should refuse to support my present position [regarding the right of the film to be shown] I, together with the Central Committee of Georgia, will lodge a formal complaint in the highest circles of our party.... [We must] assist the flourishing of our cinema, and not be narrow-minded about approaching all films with the yardstick of 'pure Soviet films." "70

68. For a description of the function and structure of Glavrepertkom, see especially the periodical Narodnoe obrazovanie, 1924, no. 4-5, p. 243. A complete text of the Central Executive Committee's definition of its role and function can be found in Sbornik zakonov $i$ postanovlenii o trude rabotnikov iskusstva (Moscow, 1925), pp. 138-41.

69. For a description of Lunacharsky's personal authority within the Commissariat, see especially a statement by Lenin in Narodnoe prosveshchenie, 79 (November 20,1921): $5-6$. See also the observations of a high-ranking member of the Commissariat during this period, V. Shulgin, in his Pamiatnye vstrechi (Moscow, 1958), pp. 74-75, and the personal observations of Lenin's widow, Krupskaia, an original member of the Collegium of the Commissariat of Education, in Komsomolskaia pravda, Dec. 28, 1934, p. 2.

70. This letter, first published in 1960 , is reproduced in A. M. Gak and N. A. 
There are other examples of Lunacharsky's personal intervention to "save" a work of art, and he was often criticized by militants who were members of the VAPP and Vserabis (Union of Art Workers). In 1927, for example, at a theater conference, one of the delegates rose to say: "I have always maintained that 90 percent of the influence of the Main Repertorial Committee comes from the commissar [Lunacharsky] himself. Workers of the committee remember, and perhaps can present, a mass of notes by comrade Lunacharsky.... When a theater organization decides to stage an anti-Soviet [sic] play, and the Main Repertorial Committee forbids it or deletes certain scenes, that organization merely appeals to the Collegium of the People's Commissariat of Education for review, and the play is permitted."'11 Lunacharsky corroborated this view on one occasion: "Let me say that our censorship in the Main Repertorial Committee is not wholly satisfactory. During periods of conflict with our 'censors' I must frequently point out their mistakes to them. ... The committee has not yet found a sound line. It thinks of itself too much as the guardian of the public .... [but] many great theatrical successes have occurred which are not necessarily wholly in consonance with the 'contemporary scene.' "72

Lunacharsky actively advocated permissiveness. Rather than risk the obliteration of lasting works of art, he promoted vigilance against subversion through intelligent criticism. Perhaps he was trying to set himself up as a judge of what was harmful and what was not, and in doing so was walking a narrower line than the committees responsible for art censorship could or would. Evidently the political leaders trusted his judgment in such matters, for I could not find a single case in which any leading party or state personality, or any leading official party or state journal, or the party itself, criticized Lunacharsky's policies on censorship.

Those who today desire to promote the liberal image of Lunacharsky can also draw inspiration from his reputation for shielding young writers and artists from criticisms and personal reprimands. Lunacharsky often defended artists against negative and caustic critics in the pages of party and literary journals. As Lunacharsky's widow recalls, he believed he was saving these artists from "total destruction" at the hands of militant hard-liners. ${ }^{73}$ A good example of Lunacharsky's attempt to shield young experimenters is the case of the young and talented Futurist writer-poet Nikolai Aseev. Aseev had written a poem concerning the great Civil War general S. M. Budenny. ${ }^{74}$

Glagolev, eds., Lunacharskii o kino: Stat'i, vyskazyvaniia, stsenarii, dokumenty (Moscow, 1965), pp. 266-70.

71. Speech by [?] Makarian, in Puti razvitiia teatra, pp. 168-69.

72. "O teatral'noi tsenzury," in Teatr segodnia (Moscow, 1927), p. 54.

73. Lunacharskaia-Rozenel, Pamiat' serdtsa (1962), p. 37.

74. "Budennyi," in N. Aseev, Sbornik stikhov (Moscow, 1923). 
This poem, along with its author, was scathingly denounced by the critic L. Sosnovsky in Pravda (December 1, 1923). Lunacharsky responded in Pravda (December 7, 1923). He began by showing Aseev just why the criticism had been leveled and why some persons could not tolerate the experimentation and innovative techniques of many Futurists, including Aseev. Then Lunacharsky explained to his readers that even though Aseev may not have understood Budenny's real role, his motives in writing this poem and his other published works were entirely praiseworthy (Lunacharsky's open letter addresses Aseev) : "You sincerely sympathize with the revolution. . . . Most of all, you live in its tempo, its powerful tide, and you want your masterly skills to serve the revolution. ... Your poetry is permeated with real heart and soul." Lunacharsky commiserated with Aseev, saying: "Worst of all, you have been made an object lesson, and you work so very hard at your poetry.... I know that you, Comrade Aseev, and many like you work very productively and that you truly belong in the revolutionary army of artists." $\mathrm{He}$ alerted Aseev and others: "I want to warn you about Comrade Sosnovsky.... He is strong ... not only among the party intelligentsia (this is to be grieved), but with healthy peasants and proletarian readers who often side with him. . . Much of your stuff opens old sores and reddens faces. . .."T5

Such activities made Lunacharsky an inviting target for militant artists connected with Proletkult, VAPP, and "hard line" party literary critics. Lunacharsky defended himself by attacking his critics: "They think that with a few words from Marx about pulling the teeth of the bourgeoisie, and great phrases concerning the proletariat they can create a new culture ... , [but] perhaps their worst fault is their hatred of all who do not wear workers' blouses, who do not place their entire lives on party programs. . . Such is the stuff out of which nasty evangelism is made."76

Occasionally Lunacharsky was caught in the middle. The Futurists whom he tried to help sometimes criticized him for his failure to do more. Sergei Tretiakov, one of the Futurists, said of Lunacharsky's theater policy: "What kind of logic is it that spends 100,000 rubles for a monument to Ostrovsky, when the theater of Meyerhold is balancing on a cashbox of deficits?'77 Lunacharsky tried to assure them that he was providing the maximum help available, given the economic conditions and political atmosphere of the NEP.

Many of the émigrés thought Lunacharsky a creation of the devil. I. A. Bunin, a talented émigré writer who received the Nobel Prize for Literature in 1933, exclaimed in 1923: "What sort of progress is drama making under Lunacharsky? Not a single play has come out of Russia since the revolution.

75. "Kak nekhorosho vykhodit," in Sobranie sochinenii, $2: 256,254,257$.

76. "L. D. Trotskii o literature," in Pechat" i revoliutsiia, 1923, no. 7, p. 3. In this article Lunacharsky agreed on most points with Trotsky's views.

77. Cited from "LEF i NEP," in LEF, 2 (1923): 76. 
... Those who are in power have no taste for drama, do not understand anything worthwhile."78

Despite these and other criticisms, Lunacharsky tried to walk the tightrope of supporting variety in artistic expression. He supported extreme proletarians as well as some whom many labeled counterrevolutionaries. His writing, debates, and activities were permeated with the spirit of freedom of artistic expression.

Lunacharsky's contemporary detractors have attempted to take the force out of the Lunacharsky legend by impugning his character, questioning his consistency, reinterpreting his theories, and in general calling into question the liberal image which others have created for him. It appears to this writer that those who support the liberal image of Lunacharsky have a much firmer foundation. Regardless of who ultimately "wins," the controversy has already had its desired effects. It has aired grievances, cleared up positions, and brought into the open important topics of continuing and vital interest to the Soviet world of art.

78. Quoted from an interview with Bunin in Stephen Graham's The Dividing Line of Europe (New York, 1925), p. 194. 